\title{
The Application of Analytical Hierarchy Process as Supporting Systems of Decision-Making in Individual Tuition Fee of Students of Universitas Sriwijaya
}

\author{
Hardini NOVIANTI ${ }^{1}$, Megah MULYA ${ }^{2}$, and Ihsan JAMBAK ${ }^{3}$
}

${ }^{1}$ Faculty of Computer Science, Universitas Sriwijaya, Indonesia

\begin{abstract}
Universitas Sriwijaya, as one of public universities in Indonesia, has already been implementing individual tuition fee from the beginning. To date, individual tuition fee in Universitas Sriwijaya has been calculated by using a certain application as a supporting system of decision making. Unfortunately, it had not worked as what expected for the absence of effective method in calculating the fee. Regarding the problem stated before, the researcher intended to create a better counting system by using Analytical Hierarchy Process (AHP) method and Supporting System of Decision-making of Individual Tuition Fee of Students of Universitas Sriwijaya.
\end{abstract}

Keywords: Supporting System of Decision-Making, Analytical Hierarchy Process, Individual Tuition Fee

\section{INTRODUCTION}

Individual tuition fee covers a part of tuition fee paid for instruction or teaching, usually for higher education on the basis of economic status of a student. Tuition fee itself can describe any payment made for instruction of each student for each term based on what program the students take in a public university while individual tuition fee is set in accordance with student's tuition fee reduced by public spending (Tahir, 2016).

Universitas Sriwijaya (Unsri) has been implementing individual tuition fee since the beginning in academic year 2013/2014. There have been many changes on administration service system in order to calculate or describe the fee of each student. To date, individual tuition fee in Universitas Sriwijaya has been calculated by using a certain application as a supporting system of decisionmaking. Unfortunately, it had not worked as what expected for the absence of effective method in calculating the fee. Besides, the application could not answer some questions, for instance, monthly installment by the parents.

Regarding the problems stated above, the researcher intended to create a better counting system to reach the effective calculation based on the student's economic status and to ease the data description as well.

\section{LITERATURE REVIEW}

\section{Supporting System of Decision-making}

Supporting system of decision-making is defined as a process of how to decide something with the help of computer system by processing the data and the implementation of a certain method to resolve all unstructured problems. The existence of this system was not created to replace the task of decision makers, but to assist them for a better decision making. The decision was made by analyzing the data findings and at last it became a decision of structured problems.

\section{Analytical Hierarchy Process (AHP) Method}

Analytical method is viewed as a comprehensive decisonmaking system that works by calculating the qualitative and quantitative data. Basicaly, this method is urged to minimize all deficiencies of the previous calculation systems. In using the $A H P$ to model a problem, one needs a hierarchic or a network structure to represent that problem and pairwise comparisons to establish relations within the structure by measuring and regulating the impact of system error components (Saaty, 2001).

\section{METHOD}

In accordance with the developmental system method, the researcher analysed the system in four phases. Here are:

1. Intelligence phase

2. Design phase

3. Choice phase

4. Implementation of solution

This analysis is used to decide the level of individual tuition fee of a student. Below is the simulation of the calculation system of the individual tuition fee of a student.

1. Determine the criteria as a key of decisionmaking. In this method, there must be a set of rubric and component needed to determine the level of individual tuition fee of a student. The description is as follows. 
Table 1. Rubrics

\begin{tabular}{|l|l|l|}
\hline C & Criteria & Weight \\
\hline C1 & Father's job & 10 \\
\hline C2 & Father's income & 20 \\
\hline C3 & Mother's job & 10 \\
\hline C4 & Mother's income & 20 \\
\hline C5 & Housing & 10 \\
\hline C6 & Cars & 10 \\
\hline C7 & Motorcycles & 5 \\
\hline C8 & Electricity and water bills & 5 \\
\hline C9 & Number of dependents & 5 \\
\hline C10 & Amount of installment & 5 \\
\hline
\end{tabular}

1. Determine sub-criteria of father's job.

Table 2. Father's Job

\begin{tabular}{|c|c|c|}
\hline No. & Job & $\begin{array}{c}\text { Assessment } \\
\text { Index }\end{array}$ \\
\hline 1 & State-owned Enterprises & 8 \\
\hline 2 & Entrepreneur & 7 \\
\hline 3 & $\begin{array}{c}\text { Civil servant/Police } \\
\text { officer/Indonesian National Army }\end{array}$ & 6 \\
\hline 4 & Private employee & 5 \\
\hline 5 & Retirement & 4 \\
\hline 6 & Labor & 3 \\
\hline 7 & Farmer & 2 \\
\hline 8 & Unemployed & 1 \\
\hline
\end{tabular}

2. Determine the sub-criteria of father's income as described as follows.

Table 3. Father's Income

\begin{tabular}{|c|c|c|}
\hline No. & Income & $\begin{array}{c}\text { Assessment } \\
\text { Index }\end{array}$ \\
\hline 1 & $<500.000$ & 1 \\
\hline 2 & $500.000-1.000 .000$ & 2 \\
\hline 3 & $1.000 .000-2.000 .000$ & 3 \\
\hline 4 & $2.000 .000-3.000 .000$ & 4 \\
\hline 5 & $3.000 .000-4.000 .000$ & 5 \\
\hline 6 & $4.000 .000-5.000 .000$ & 6 \\
\hline 7 & $5.000 .000-6.000 .000$ & 7 \\
\hline 8 & $>6.000 .000$ & 8 \\
\hline
\end{tabular}

3. Determine sub-criteria of mother's job as follows

Table 4. Mother's Job

\begin{tabular}{|c|c|c|}
\hline No. & Job & $\begin{array}{c}\text { Assessment } \\
\text { Index }\end{array}$ \\
\hline 1 & State-owned Enterprises & 8 \\
\hline 2 & Entrepreneur & 7 \\
\hline 3 & $\begin{array}{c}\text { Civil servant/Police } \\
\text { officer/Indonesian National } \\
\text { Army }\end{array}$ & 6 \\
\hline 4 & Private employee & 5 \\
\hline 5 & Retirement & 4 \\
\hline 6 & Labor & 3 \\
\hline 7 & Farmer & 2 \\
\hline 8 & Unemployed & 1 \\
\hline
\end{tabular}


4. Determine the sub-criteria of mother's income as described as follows.

Table 5. Mother's Job

\begin{tabular}{|c|c|c|}
\hline No. & Income & Assessment Index \\
\hline 1 & $<500.000$ & 1 \\
\hline 2 & $500.000-1.000 .000$ & 2 \\
\hline 3 & $1.000 .000-2.000 .000$ & 3 \\
\hline 4 & $2.000 .000-3.000 .000$ & 4 \\
\hline 5 & $3.000 .000-4.000 .000$ & 5 \\
\hline 6 & $4.000 .000-5.000 .000$ & 6 \\
\hline 7 & $5.000 .000-6.000 .000$ & 7 \\
\hline 8 & $>6.000 .000$ & 8 \\
\hline
\end{tabular}

5. Determine the status of housing as described in the following table

Table 6. Housing

\begin{tabular}{|c|c|c|}
\hline No. & Condition & $\begin{array}{c}\text { Assessment } \\
\text { Index }\end{array}$ \\
\hline 1 & Rent & 3 \\
\hline 2 & Temporary Living & 5 \\
\hline 3 & Private owned house & 8 \\
\hline
\end{tabular}

6. Determine sub-criteria of car ownership as follows

Table 7. Car Ownership

\begin{tabular}{|c|c|c|}
\hline No & Car Ownership & Assessment Index \\
\hline 1 & 0 & 1 \\
\hline 2 & $1-2$ & 5 \\
\hline 3 & $>2$ & 8 \\
\hline
\end{tabular}

7. Determine sub-criteria of motorcycle ownership as follows

Table 8. Motorcycle Ownership

\begin{tabular}{|c|c|c|}
\hline No & Motorcycle Ownership & Assessment Index \\
\hline 1 & 0 & 3 \\
\hline 2 & $1-2$ & 5 \\
\hline 3 & $>2$ & 8 \\
\hline
\end{tabular}

8. Determine the electricity and water bills as described as follows.

Table 9. Electricity and Water Bills

\begin{tabular}{|c|c|c|}
\hline No & $\begin{array}{c}\text { Electricity and Water } \\
\text { bills }\end{array}$ & Assessment Index \\
\hline 1 & $<50.000$ & 1 \\
\hline 2 & $50.000-100.000$ & 2 \\
\hline 3 & $100.000-200.000$ & 3 \\
\hline 4 & $200.000-300.000$ & 4 \\
\hline 5 & $300.000-400.000$ & 5 \\
\hline 6 & 400.000 .450 .000 & 6 \\
\hline 7 & $450.000-500.000$ & 7 \\
\hline 8 & $>500.000$ & 8 \\
\hline
\end{tabular}


9. Determine the sub-criteria of number of dependents as described as follows.

Table 10. Number of Dependents

\begin{tabular}{|c|c|c|}
\hline No. & $\begin{array}{c}\text { Number of } \\
\text { Dependents }\end{array}$ & Assessment Index \\
\hline 1 & 8 & 1 \\
\hline 2 & 7 & 2 \\
\hline 3 & 6 & 3 \\
\hline 4 & 5 & 4 \\
\hline 5 & 4 & 5 \\
\hline 6 & 3 & 6 \\
\hline 7 & 2 & 7 \\
\hline 8 & $<2$ & 8 \\
\hline
\end{tabular}

10. Determine the sub-criteria of amount of installment as described as follows.

Table 11. Amount of Installment

\begin{tabular}{|c|c|c|}
\hline No. & $\begin{array}{c}\text { Amount of } \\
\text { Installment }\end{array}$ & Assessment Index \\
\hline 1 & 0 & 1 \\
\hline 2 & $0-500.000$ & 2 \\
\hline 3 & $500.000-1.000 .000$ & 3 \\
\hline 4 & $1.000 .000-2.000 .000$ & 4 \\
\hline 5 & $2.000 .000-3.000 .000$ & 5 \\
\hline 6 & $3.000 .000-4.000 .000$ & 6 \\
\hline 7 & $4.000 .000-5.000 .000$ & 7 \\
\hline 8 & $>5.000 .000$ & 8 \\
\hline
\end{tabular}

11. Alternatives are different objects and have the same opportunity to be chosen by the decision makers. In this case, the alternatives were the prospective students of Individual Tuition Fee grant, Here are the alternatives.

Tabel 12. Names of Aletrnaties

\begin{tabular}{|c|c|c|c|}
\hline No & Alternatives & Names & Study program \\
\hline 1 & $\mathrm{~A}_{1}$ & Ade Andreas & $\begin{array}{c}\text { Informatics } \\
\text { Engineering }\end{array}$ \\
\hline 2 & $\mathrm{~A}_{2}$ & Atikah Haniyah & Marine Science \\
\hline 3 & $\mathrm{~A}_{3}$ & Fikri Fauzi & Management \\
\hline
\end{tabular}

\section{FINDINGS AND INTERPRETATIONS}

\section{DFD Level 0}

\section{Data Flow Diagram (DFD)}

Data Flow Diagram is a representation of process of data flow and system process created. Here is the future plan DFD.

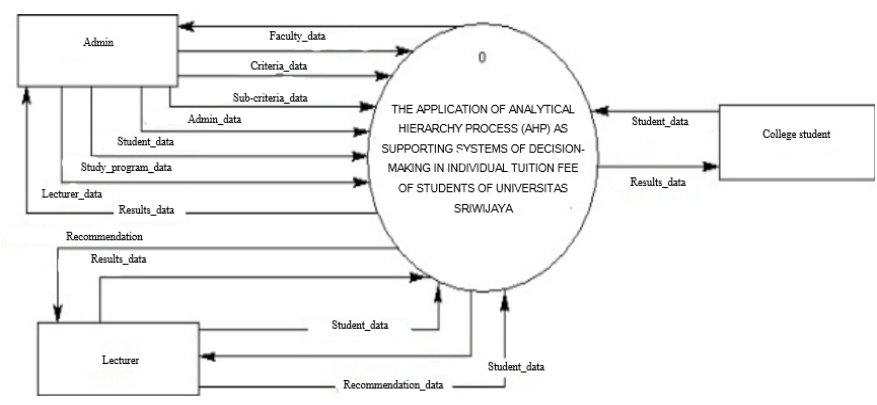

Figure 1. DFD Level 0 
Notes :

1. Administrator entity is used to $\log$ in and process the data

2. Student entity is used to input students' data

3. Study program entity is used to store the data of a certain study program

4. Faculty entity is used to store data of a faculty

5. Lecturer's entity is used to store the lecturer's data

6. Output entity is used to show the alternatives

\section{Login}

Log in screen has three levels; they are student, lecturer and administrator.

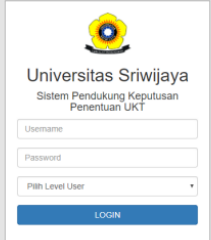

Entity Relationship Diagram (ERD) is a model used to build a system. ERD represents the link among restored data in database system.

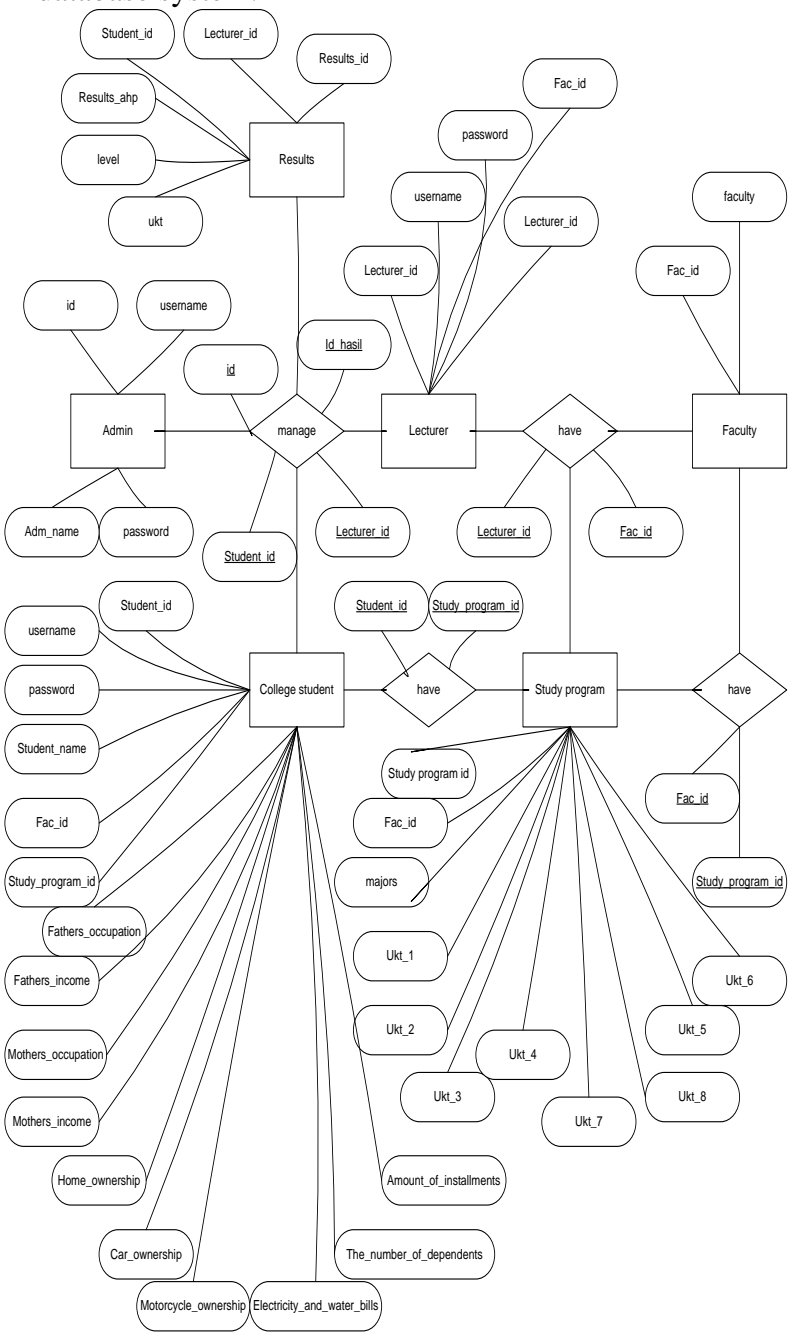

Figure 3. ERD
Figure 4. $\log$ in screen

\section{STUDENT HOME}

Home is the main screen appeared when the students have already logged in.

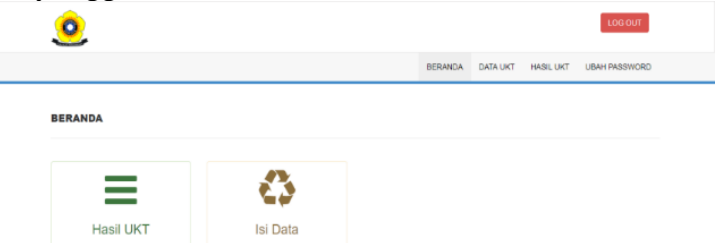

Figure 5. Home (Student)

\section{Student's Form Data}

This screen covers all data of the students to ease the calculation of their individual tuition fee.

ㅇ․

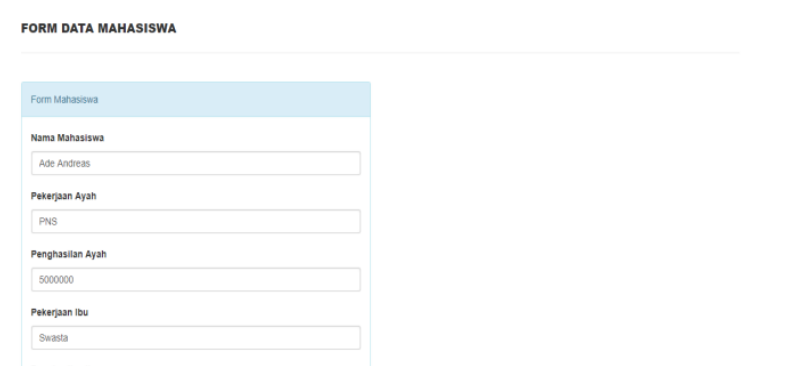

Figure 6. Form Data (Student) 


\section{LECTURER Home}

Home (Lecturer) displays Data of the Students who had already updated their data on Student's Form. For those who had not got the weight from the lecturer, their data will appear in this Home while those who had got the weight from their lecturer with the status "Not Yet Calculated" the data will not appear due to the fact that the weight had already been calculated.

\section{(2)}
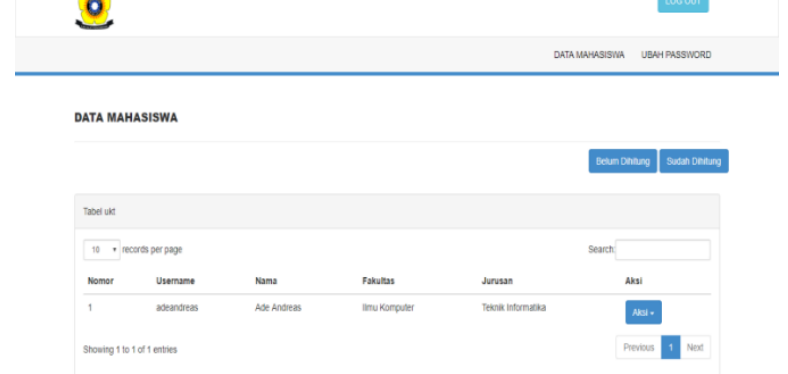

Figure 7. Home (Lecturer)

\section{Display of Management Recommendation}

This screen is created to manage the recommendation in order to decide individual tuition fee of a student properly on the basis of their condition.
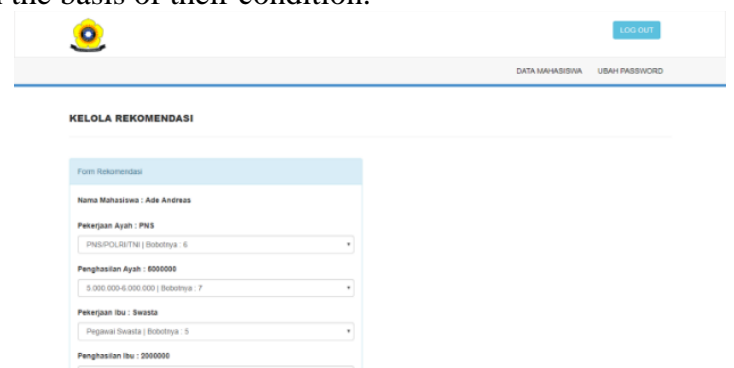

Figure 8. Display of Management Rommendation

\section{ADMINISTRATOR Home}

This screen appears once the administrator has already logged in to their account.

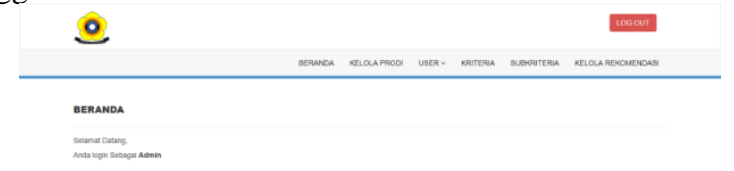

Figure 9. Home (Administrator)

\section{Data Display of Study Program}

This displays in order to let the certain study program plan to complete the data of a faculty and study program. This aims at determining individual tuition fee required for a certain study program of a faculty. This level of individual tuition fee varies among study programs in each faculty.

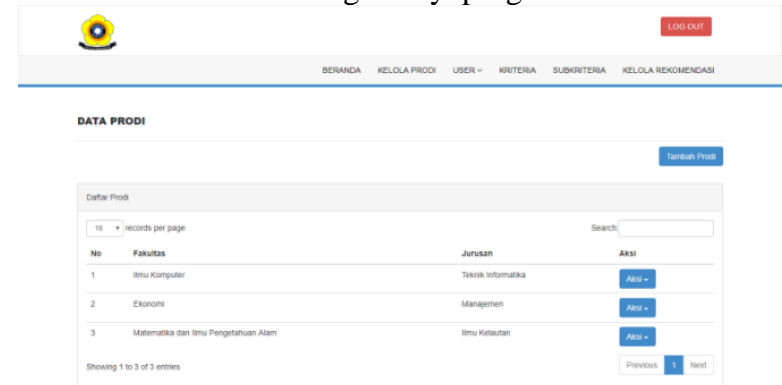

Figure 10. Home (Study Program)

\section{Display of Data of Lecturer}

This display functions to complete lecturer's data who have the responsibility to place the weight of the students' Tampilan Data Dosen merupakan tampilan untuk mengisi data dosen yang bertanggung jawab untuk mengisi bobot Mahasiswa

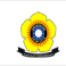

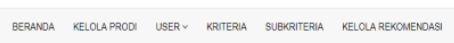

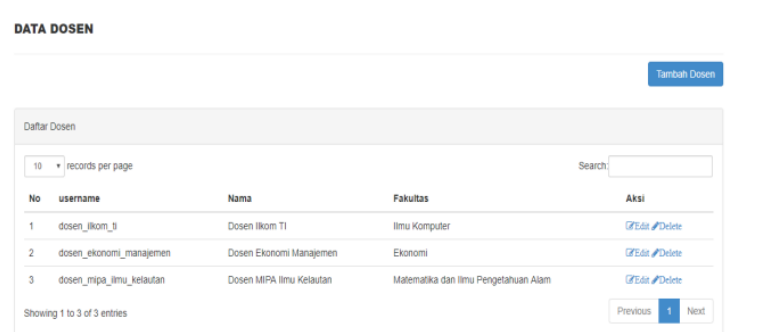

Figure 11. Display of Data of Lecturer

\section{Display of Data of a Student}

This display is aimed at completing or changing the data filled by the student himself/herself. The student is asked to $\log$ in at first before they start completing the data.

().

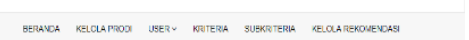

DATA MAHASISWA

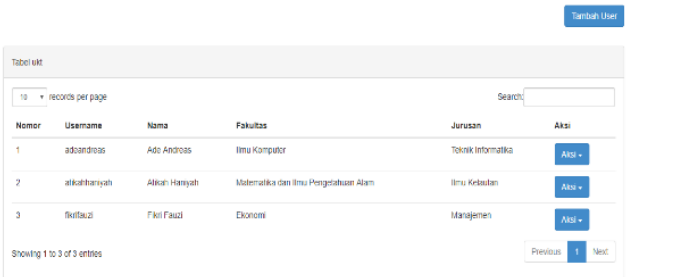

Figure 12. Display of Data of a Student 


\section{Display of Data of Administrator}

This display works for adding, changing, and omitting the data input as an administrator.

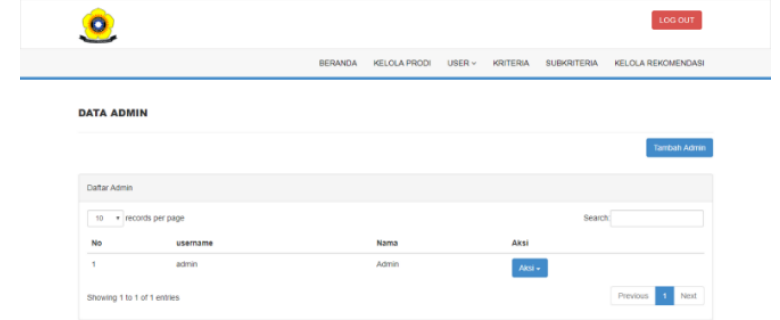

Figure 13. Display of Data of Administrator

\section{Display of Criterion Data}

This covers some criteria before determining the level of individual tuition fee. This contains "add", "edit" and "remove" menu.
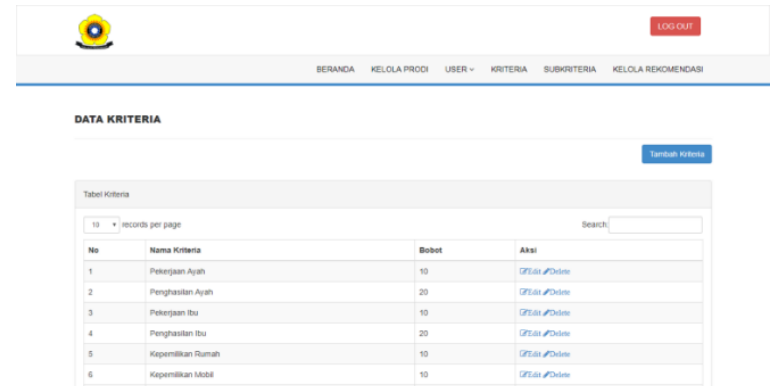

Figure 14. Display of Criterion Data

\section{Display of Sub-criterion Data}

This display contains "add", "edit", and "remove" menu on the screen.
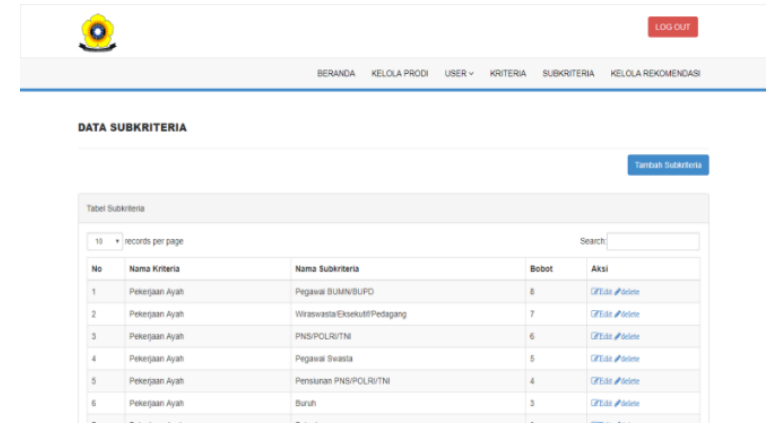

Figure 15. Display of Sub-criterion Data

\section{CONCLUSIONS}

From the findings above, it can be summed up that the method applied to decision-making; that is Analytical Hierarchy Process (AHP) can be done faster and easier to determine the weight or criteria who granted the individual tuition fee.

\section{REFERENCES}

[1] Fitriyani. (2012). Penerapan AHP Sebagai Model Sistem Pendukung Keputusan Pemilihan Rumah Sakit Bersalin Contoh Kasus Pangkal Pinang, 2.

[2] Muslihudin, M., \& Rohmah, L. (2014). Sistem Pendukung Keputusan Seleksi Siswa Berprestasi Pada SMK Nurul Huda Pringsewu menggunakan Metode AHP,

[3] Sommerville, Ian. (2011). Software Engineering (Rekayasa Perangkat Lunak). Jakarta: Erlangga.

[4] Tahir, I. (2016). Model Pengambilan Keputusan Penentuan Uang Kuliah Tunggal (UKT), 1-2.

[5] Utami, Winda Pangesti. (2012). Penerapan Algoritma Iterative Dichotomiser Three untuk Pemilihan Dosen Pembimbing. Universitas Kristen Satya Wacana: Jawa 